\title{
ALEPPO BEFORE AND AFTER THE WAR $2010-2018$
}

\author{
G. Fangi ${ }^{1}$ \\ ${ }^{1}$ Università Politecnica delle Marche, Ancona, Italy, gabrielefangi@gmail.com
}

\author{
Commission II, WG II/8
}

KEY WORDS : Syrian Threatened Cultural Heritage, Spherical Photogrammetry

\begin{abstract}
:
What remains of Cultural Heritage in Syria? And in particular in Aleppo? Aleppo, according to UNESCO, is the oldest city in the world. The first settlements date back to 12,000 years ago, the first evidence of the city to 8,000. The A. visited the city in October 2018 at the invitation of the Syrian Trust for Development. He previously went to Syria for a photographic tour in 2010. It was a unique opportunity to document some noticeable buildings and monuments, later on affected by the war. When the war began in 2012, the A. retrieved the photographs and gave them to his students, who then ran some 28 projects of Cultural Heritage items. They are small monuments or small projects, neither complete not very accurate, but sometimes they are unique for the monuments that have already disappeared. In 2017 the book Reviving Palmyra was published, whose main author is the Finnish archaeologist Minna Silver. The book shows the results of the surveys of some monuments of Palmyra, including the Roman theater, the temple of Bel, the triumphal arch and the funerary tower of Al-Habel. The A. made an exibition of the these projects in Ancona, Italy, and produced a video of the exibition, which was then published online. Reme Sackr saw the video and invited the A. to visit Syria. She is a Syrian woman of the Syrian Trust for Development, a Syrian NGO for reconstruction of Syria. She is responsible for the Living Heritage Program inside the Trust, in practice responsible for the reconstruction and the restoration of the monuments in Syria. So in October 2018 the A. went to Aleppo, Syria, for a second time. The present paper shows some results and comparisons for same monuments before and after the war. The objects of the survey are some parts of the Citadel walls, the entrance tower of the Citadel, the southern tower, one mosque and the minaret of the Citadel mosque. One of the first monuments to be restored will be the minaret of the Great Omoyyad Mosque in Aleppo. Some monuments, the minority, are apparently in good condition, seemingly untouched by the war. Some are badly damaged and unsafe. They must first be made sade and subsequently restored. Finally, other monuments - and these are the majority - no longer exist because they have been destroyed to their very foundations. It seems that the war, besides the population, has particularly targeted monuments, perhaps because they represent the soul and history of a people and a country. For them the problem arises whether to reconstruct or not, and in case of reconstruction with which instruments and with which technique, if there are previous findings. This is precisely the case of the minaret. Here they will try to reconstruct the monument where it was, as it was and with the same materials, with possibly the same blocks in the same position they were in. For this task, however, their identification is necessary. The minaret is the most important monument in Syria, because it is the symbol of the country. It was built in 1092, and its restoration was completed in 2007. A special commission now follows the restoration work. It is composed by public, religious and technical-scientific authorities. They are the same university professors who carried out the restoration of 2007 and now curate the reconstruction. Work began in February 2018. The minaret stones were placed in the square of the mosque. Using a crane they raised the stones one by one, then photographed them from all positions. They then proceeded to the identification stage. A computer program was created in MATHLAB ${ }^{8}$ which could carry out the first automatic selection of 6-8 possible candidates. The operator then manually selected the choosen one. Of the 1300 stones of the external face, $40 \%$ have already been recognized. The high-resolution photographs of the A. of 2010 will help the identification. It is hoped to reach $70 \%$. Many blocks are no longer usable because they are broken, being limestone and therefore fragile. They no longer have the necessary resistance and will have to be replaced. A museum will be set up for the reconstruction of the minaret and the mosque. It is hoped to complete the work in two years. The surveying technique used by the A. is Spherical Photogrammetry. He published in 2018 The book of Spherical Photogrammetry a collection of related papers and experiences. This technique has been set up by the A. since 2006. It is based on spherical panoramas. These are cartographic representations on planes of spheres, on which the partially overlapping photographs taken from a single shooting point, are projected. Its main feature is the shooting speed. The technique is very much suitable for heritage documentation and the A. hopes to transfer it to the students of the local faculty of architecture. In this last mission, especially for the interiors, the A. made extensive use of Panono, a multi-image camera capable of covering $360^{\circ}$. These results prove undoubtedly that photogrammetry is an essential instrument for the $3 \mathrm{D}$ documentation and digital preservation of cultural heritage.
\end{abstract}




\section{INTRODUCTION}

"There are few countries that can rival Syria in terms of numbers of sites of archaeological and historical interest. It is simply an open book on the history of mankind over the last 10,000 y ears." (Burns, 2017) ${ }^{1}$.

The war in Syria began in 2012 and although there are still pockets of resistance in the country, it is likely that it is almost finished. To get a more precise idea of the situation, one can consult R. Burns, former Australian ambassador to Syria and archaeologist. One might think that the destruction of the BBCC in Syria was complete, yet the country is so rich that the claim is false (Burns). The reconstruction of the monuments could stop according to some to preserve the current state, as a testimony of history and war. Many monuments had already undergone heavy reconstructions before the war, so their reconstruction would not be an absolute novelty. The sites that have suffered the most in the country are Aleppo and Palmira. Table 1, taken from Burns, shows the amount of monuments destroyed as a percentage of the total in the country. The reconstruction must take place with the original materials, respecting the monument as much as possible. And this is the case of the segiuchid minaret of the great mosque of the Omy yads in Aleppo.

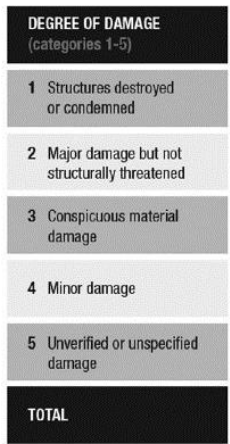

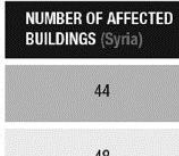

48

67

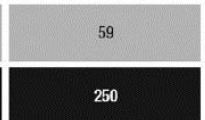

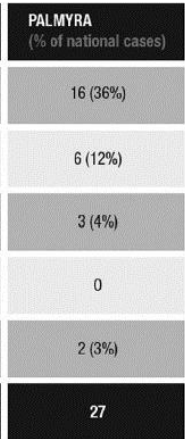

27
Table 1 - Table of damage estimates for March 2017, with breakdown for Aleppo and Palmyra (R.Burns).

The A. was in Aleppo, Syria, before the war in 2010 and once again in October 2018, the latter being the occasion to produce surveys of some noticeable heritage buildings and monuments affected by the local war. The technique used is spherical photogrammetry (Fangi, 2007; Fangi and Nardinocchi, 2013), fast in the acquisition phase, based on very simple photographic equipment. Results of spherical photogrammetry applied to the Syrian monuments were presented in Fangi and Wahbeh (2013) - digital reconstruction of the minaret of the Great Mosque or Umayy ade Mosque destroyed in 2012, Fangi (2015) and Fangi et al. (2016).

In October 2017 the Polytechnic University of Marche organized an exhibition entitled "The Lost Syria, the Geomatics documents", with 28 surveys displayed in large panels and supported by videos. The students were responsible for carrying out the plots of the surveyed Syrian monuments (Di Stefano, 2016). A video of the 3D reconstruction was seen by Ms Reme Sakr, head of the Living Heritage Program of the Syrian Trust for Development, a Syrian NGO, and she proposed to the A. to return to Syria and visit Damascus and Aleppo. The visiting mission took place from October $1^{\text {st }}$ to October $15^{\text {th }}, 2018$. Some monuments had already been surveyed in 2010, some others were surveyed ex novo.

\footnotetext{
${ }^{1}$ In 1992, this author published Monuments of Syria, the first comprehensive survey in English of the country's archaeological sites.
}

In the following sections some of the achieved results and pre/after war comparison of same monuments (parts of the Citadel walls, the entrance tower of the Citadel, the southern tower, one madrasa, the minaret of the Citadel mosque) are presented. What is shown here is intended to be a small help only for the reconstruction of the country. A more detailed analy sis of the overall situation of the Cultural Heritage in Syria can be found in Ross Burns.

\section{THE DOCUMENTED MONUMENTS}

There are three different types of documentation for monuments:

A) Monuments available for comparison before and after the war

Minaret,

Medrasa AlHaways (interior and court),

Southern Tower and in general the walls of the citadel,

Interior facade of Khan Al Wasir caravanserai,

A very typical place inside the souq, and

Entrance gate of the Ayubbids Palace inside the Citadel.

The Citadel walls

B) Monuments where only an 'after' survey and only photographic documentation of the 'before' stage are available: Matbackh al Alami

Khan el Wazir gate

Hammam an-Nasri

C) Monuments where only "after" photographic documentation is available:

al-Aadlieh mosque,

cristian-maronite cathedral,

Medrasa e Moschea Al-Ridaieh,

Old Governor building,

al-Utrush mosque,

Aslan Dada mosque,

Al Bahrameah Mosque, and

Al-Sultanieh, Ay yubidi, 1223 D.C. Mosque.

\section{THE SURVEYS ALLOWING COMPARISON}

A complete description of the monuments hereafter shown and their history can be found in "The Great Mosque of Aleppo Muslim Heritage", in Hdjar (2007) and Gonella et al., (2005), and Ross (1992).

Al-Madina Souq is the covered souq-market located at the city center within the walled ancient part (Figure 1). With its long and narrow alleys and galleries, the Souq was the biggest covered historic market in the world, with an approximate total length of 13 kilometers. Most of the souqs date back to the 14th century. Aside from trading, the souq could receive the traders and their goods in khans (caravanserais) scattered within the souq. Most of the khans took their names after their function and location in the souq and are characterized by beautiful façades and entrances with fortified wooden doors. Al-Madina Souq is part of the Ancient City of Aleppo, a UNESCO World Heritage Site since 1986. The so-called Matbakh (kitchen) of al'Ajami of Aleppo (Figure 2) is located about 150 meters west of the Citadel, on a modern street that connects the Citadel with the Great Mosque. 


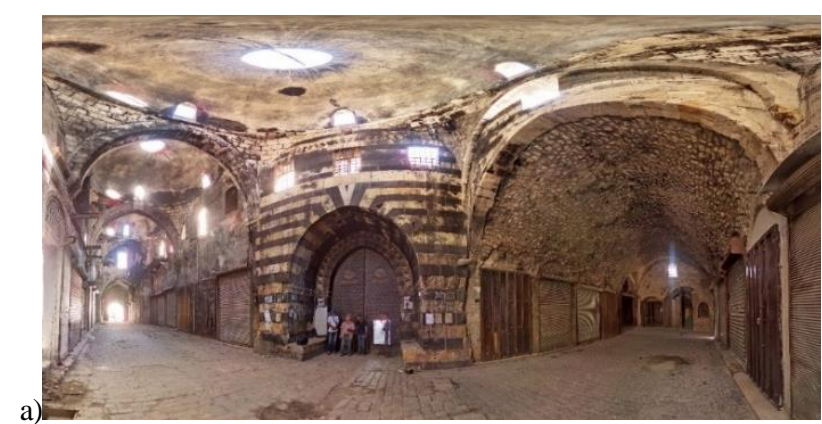

b)

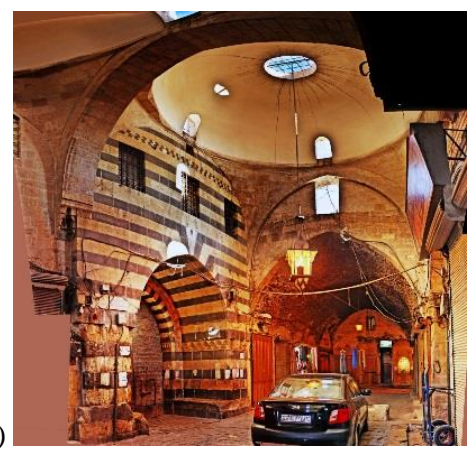

Figure 1. The old souq, current situation (a) and how it was in 2010 (b).
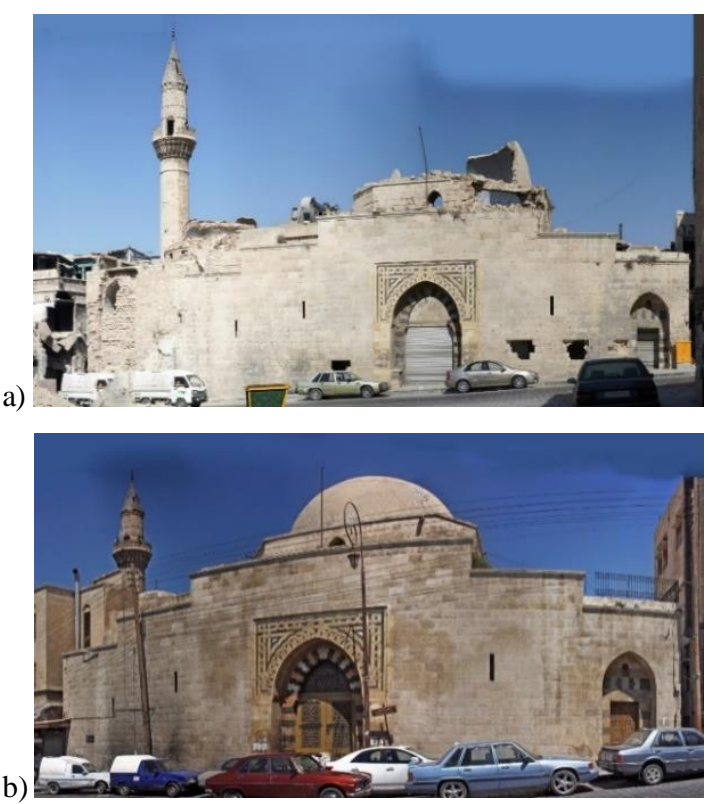

Figure 2. Matbackh al Ajami, current situation (a) and how it was in 2010 (b).

Khan al-Wazir (Figure 3) is a caravan-serray located in the old city of Aleppo between the Citadel and the Great Mosque. The Ottoman governor of Aleppo, Qara Muhammad Pasa commissioned the building between 1678 and 1682 . (https://archnet.org/sites/2865). It served as guest-house for travelers and it is in beautiful ablaq style. It seems to have little damage due to the war.

The citadel of Aleppo (see Gonella (2005), Ross (1992), et al) rises on a conical truncated hill with, 40 meters height; it has an elliptical shape with axes of $400 \times 200$ meters, directed northsouth and west-east. The city walls (Figure 4) extend for about $900 \mathrm{~m}$. To the south and to the north two defensive towers stand beyond the walls (Figures 6 and 7).
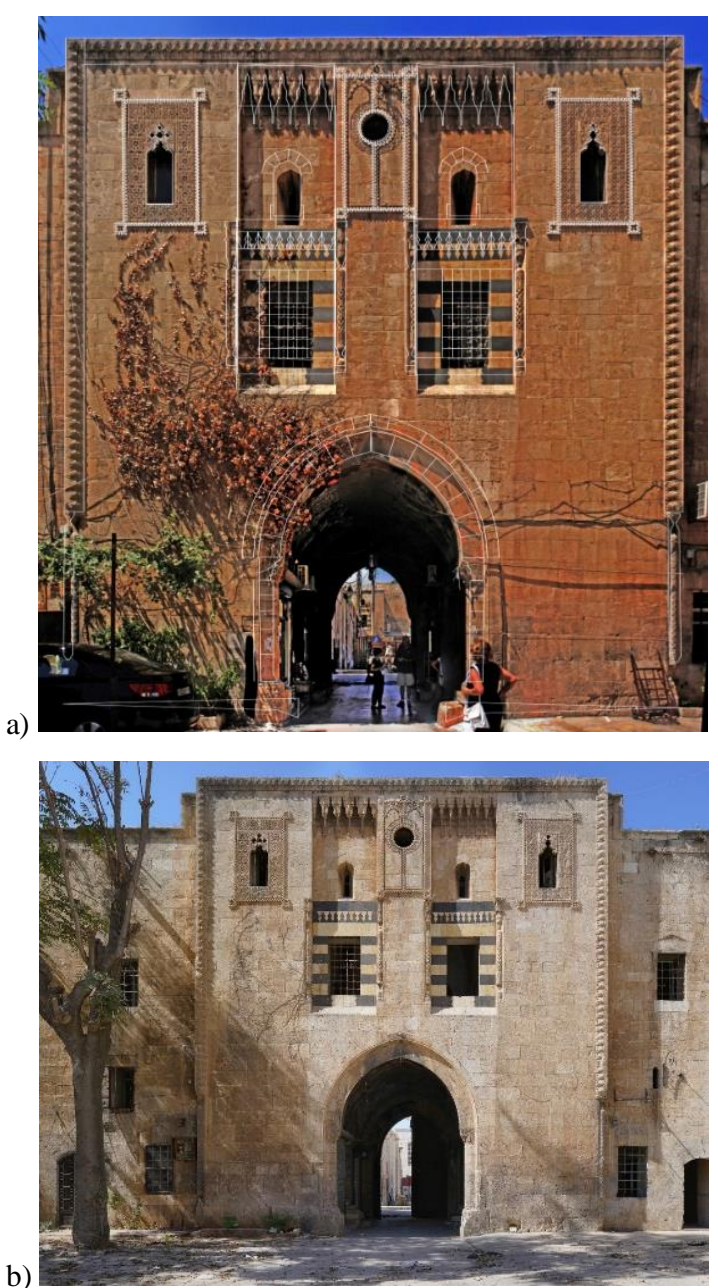

Figure 3. Khan el wazir, caravan-serray in the typical ablaq style, as it was (a) and as it is now (b). The difference in colour is very much evident, probably due to the limestone dust.

a)

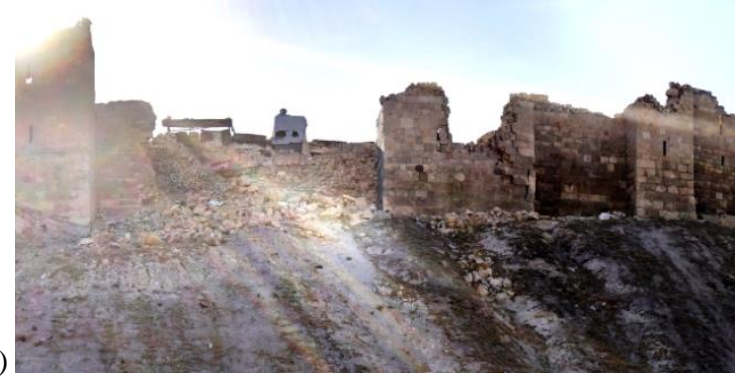

b)

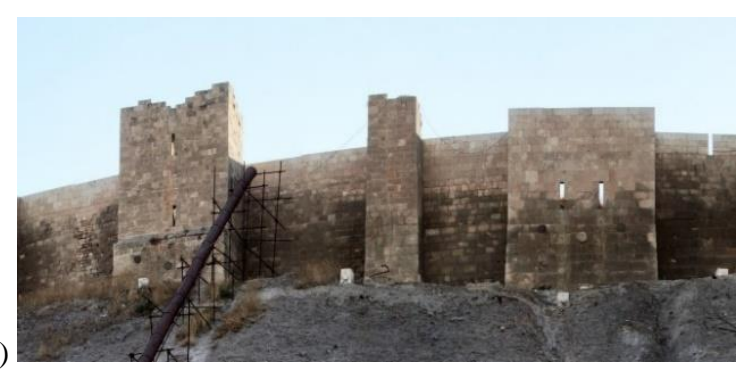

Figure 4. Citadel walls, current situation (a) and how it was in 2010 (b). A large brech is visible, produced by bombing. 

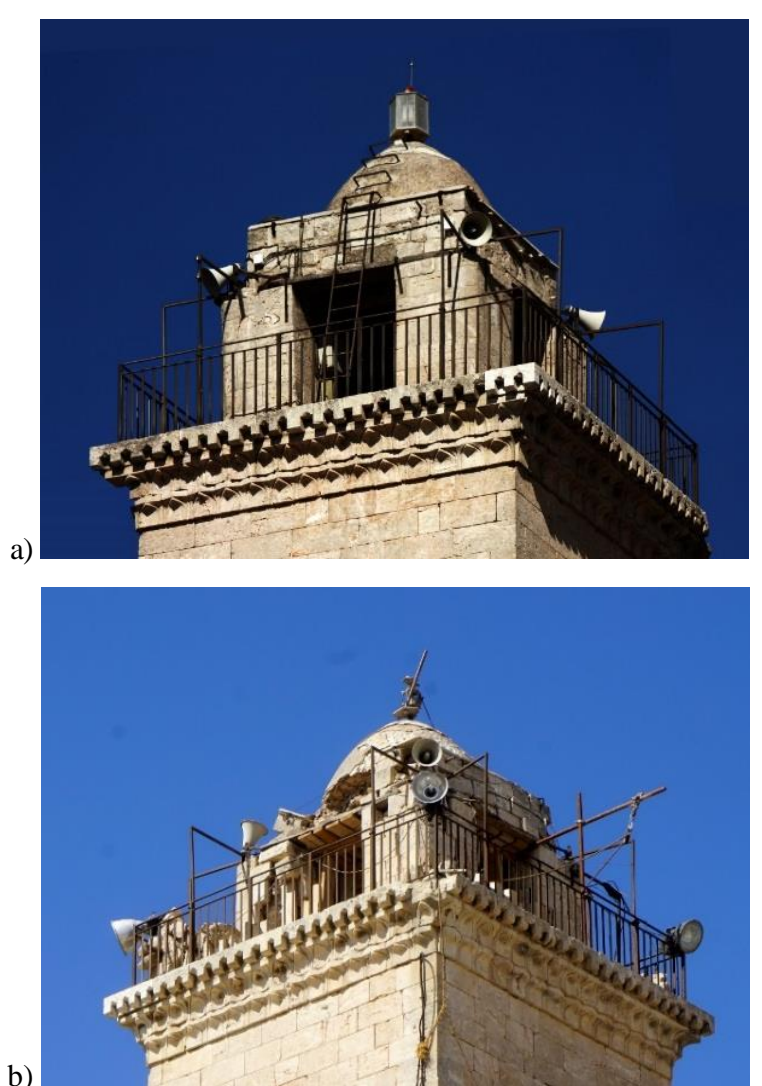

Figure 5. Minaret of the citadel mosque, current situation (a) and how it was in 2010 (b).

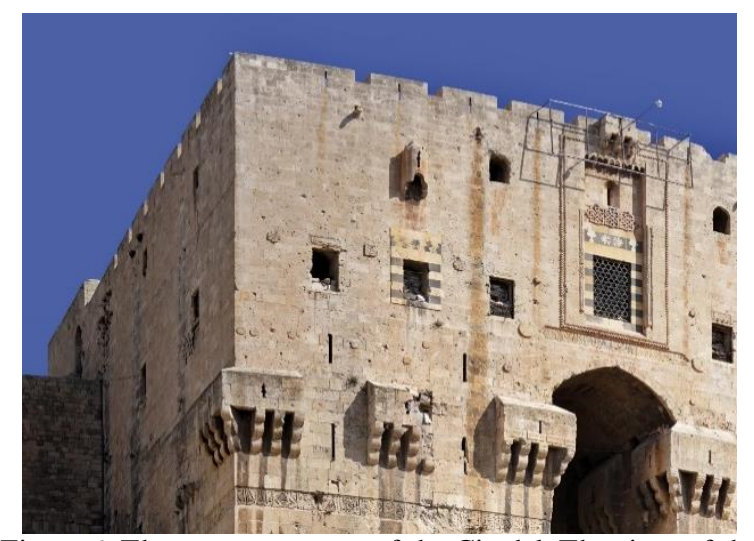

Figure 6. The entrance tower of the Citadel. The signs of the conflit are evident

The Great Mosque (or the Umayyad Mosque) of Aleppo (Figures 8. 9.10 and 11) is the largest and one of the oldest mosques in the city of Aleppo. It is located in al Jalloum district of the Ancient City of Aleppo, near the entrance to Al-Madina Souq. It was built at the beginning of the $8^{\text {th }}$ century CE. However, the current building dates to the $11^{\text {th }}$ through $14^{\text {th }}$ centuries. The minaret (Figure 5) was built in 1090-92. and was destroyed during fighting in the civil war in April 2013.
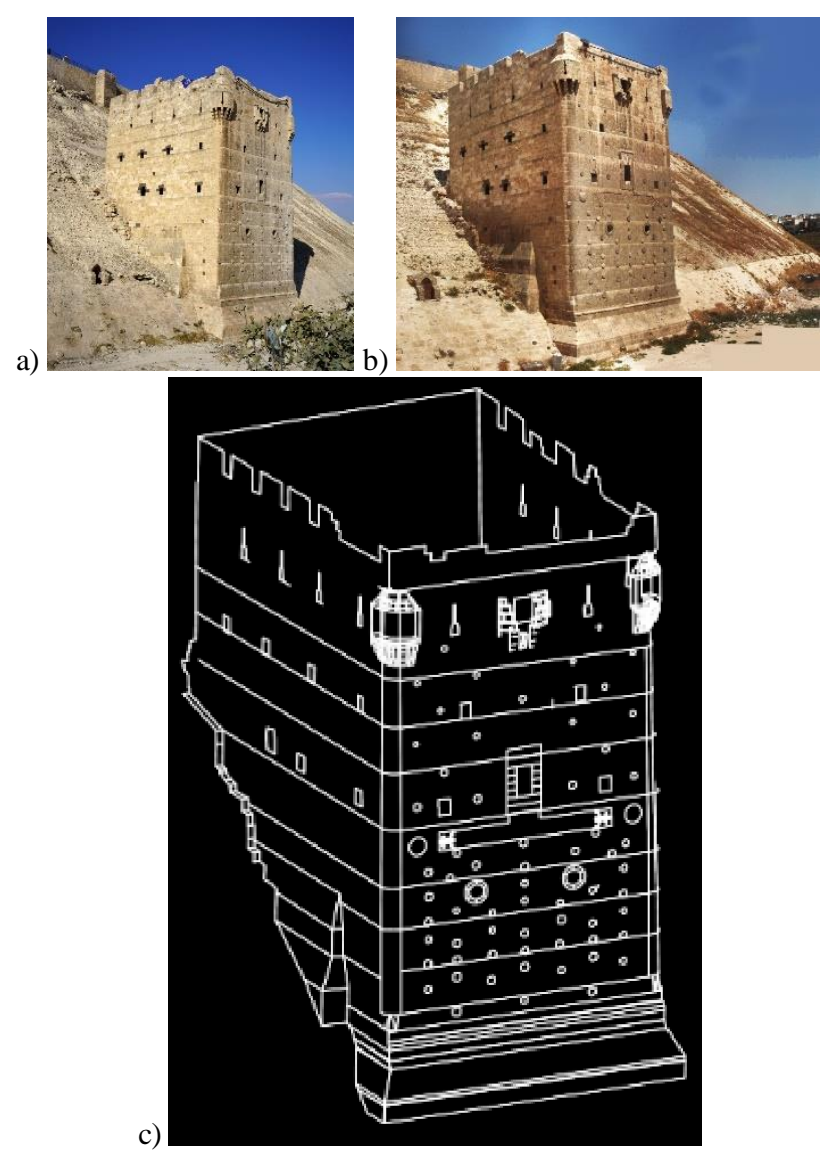

Figure 7. The Southern tower of the Citadel now (a), as it was (b) and a $3 \mathrm{D}$ restitution (c), by Oma e-Beik.

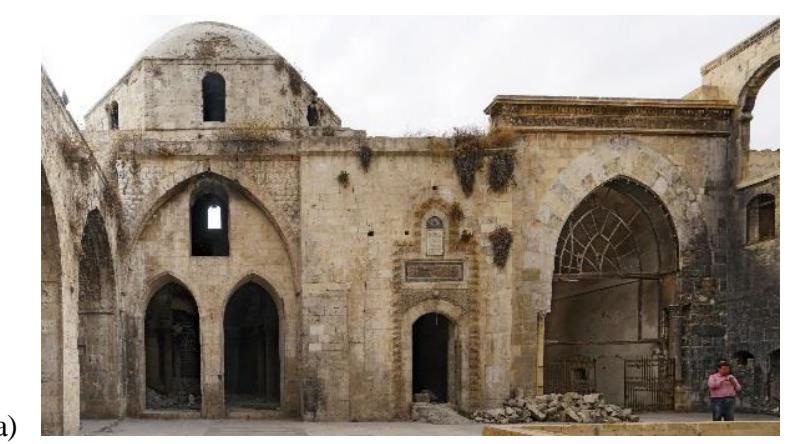

a)

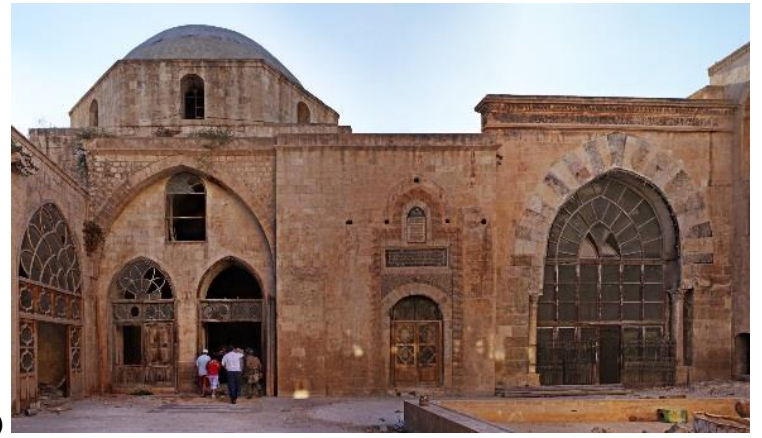




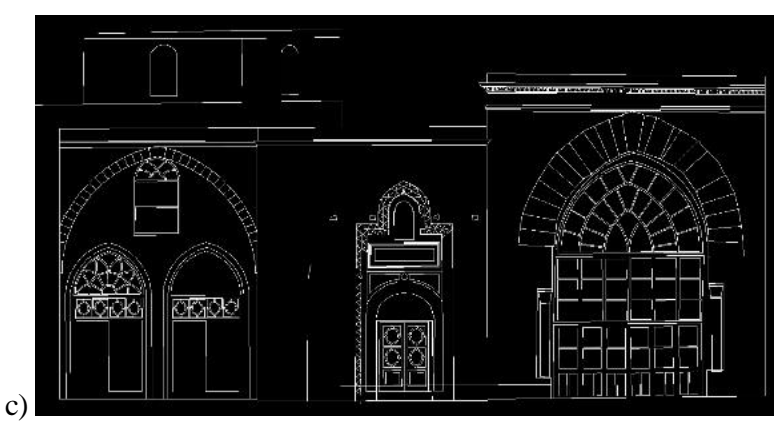

Figure 8. Al Haways Medrasa, current situation (a), how it was in 2010 (b) and 3D restitution (c) by F.Di Stefano.

a)

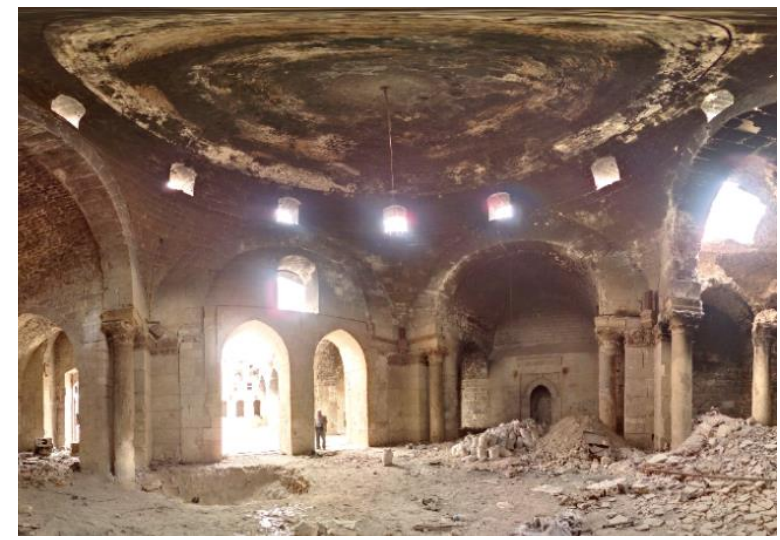

b)

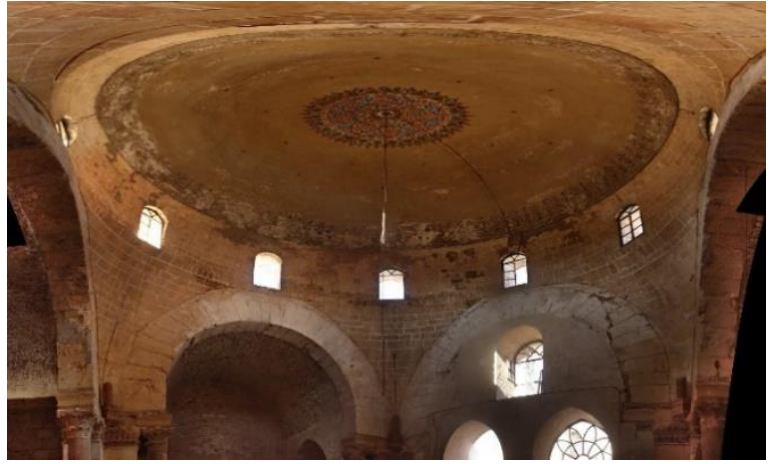

Figure 9. The el Haways Madrasa interior, current situation (a) and how it was in 2010 (b).

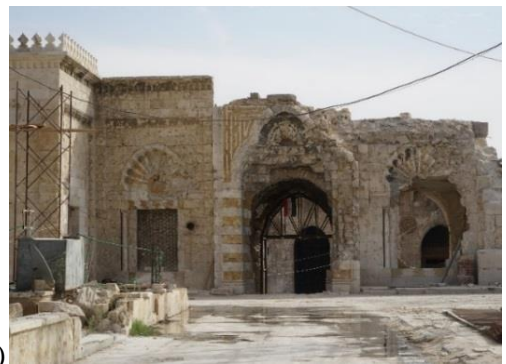

b)

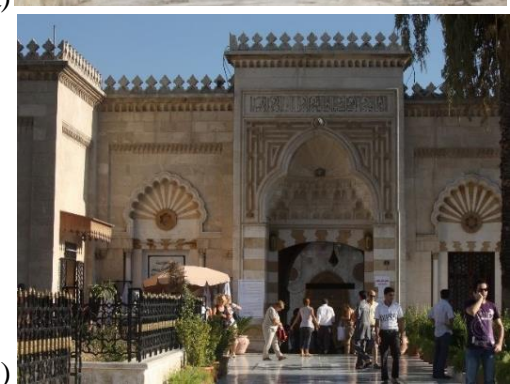

Figure 10. The entrance gate to the Great Mosque, current situation (a) and how it was in 2010 (b) a)

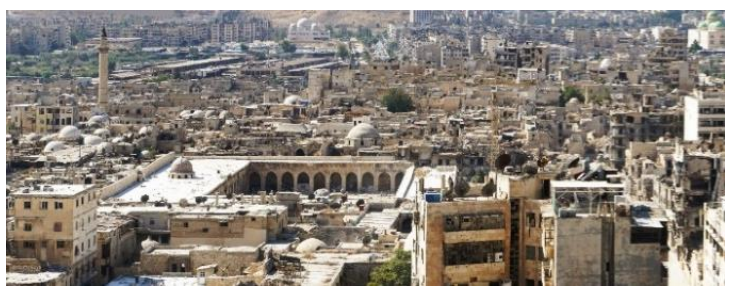

b)

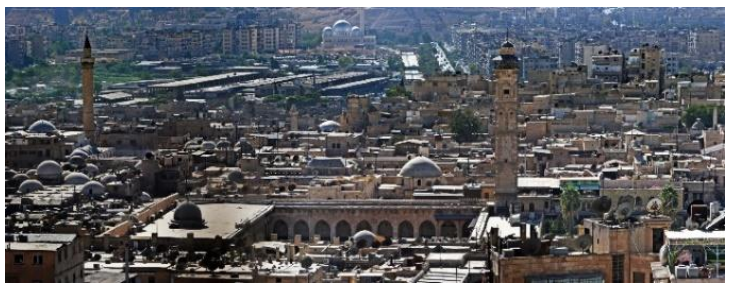

Figure 11. The Omayyadid's Great Mosque, current situation (a) and how it was in 2010 (b)

\section{THE GREAT UMAYYADS MOSQUE AND THE MINARET}

The works for the restoration of the mosque (Figure 12) and for the reconstruction of the minaret (Figure 13) began in February 2018. The minaret, located in the northwest corner of the mosque, was erected under the first sultan Seljud in 1090-92. The minaret was 45 meters tall. It had five levels that ended with an overhanging wooden balcony for the muezzin. The decoration consisted of relief ornaments. The minaret had previously been restored in 2007 , so accurate measurements are still available. A committee, composed of civil, religious, professional and academic authorities, takes care of the restoration-reconstruction work. The first phase of the restoration consists in the recognition of the external blocks that will be relocated in the same position where they were. There are in total about 2500 blocks with dimensions of $0.5 \times 0.55 \times 1.10 \mathrm{~m}$ approximately, and 1300 of them placed outside in the walls. In the court of the mosque the blocks are placed waiting for recognition and classification. The workers lift each block with a crane and take photographs of it from all positions. With a computer program written in MATHLAB® by prof. Jabreeni (Figure 17), the recognition is performed semi-automatically. The program provides 5-6 candidates and the operator makes the final choice. The A.'s high-resolution photographs of the minaret (Figure 22) will help in recognizing and confirming the identifications already made. The identification is expected to reach $70 \%$ of the total. Many blocks are broken and no longer suitable; therefore, they will be replaced. The work is expected to finish by 2020. By October 2018, 40\% of the 1300 blocks were correctly identified (Figure 16). 


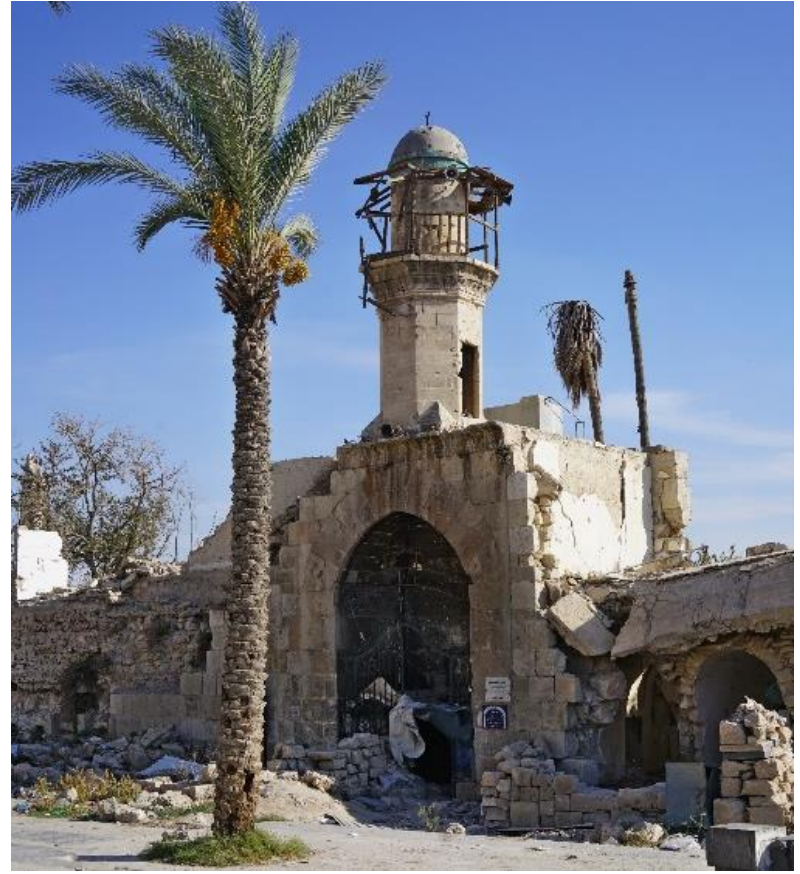

Figure 12. Al-Sultanieh, Mosque, Ayyubids, 1223 D.C. It contained the tomb of Zaher al-Ghazi, son of Saladin, the governor who restored the Citadel and built the walls.
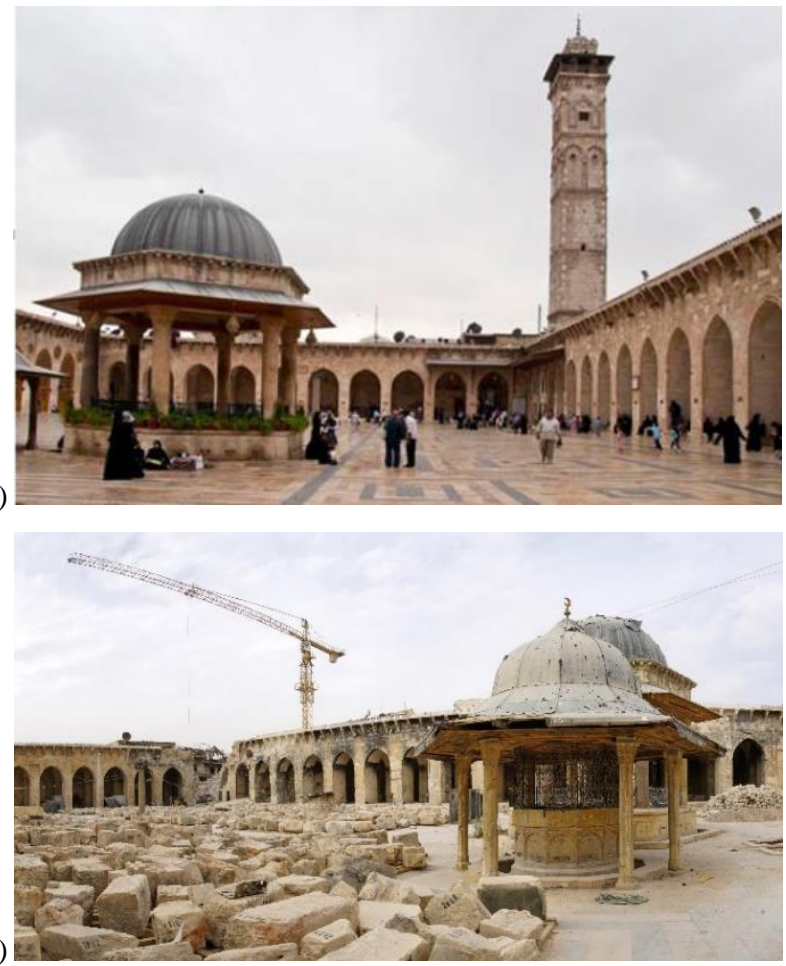

Figure 13. The Minaret of the Great Umayy ad Mosque before the war and after the war. The blocks placed on the floor of the court, are numbered, raised with the visible crane and then photographed to proceed with the identification.

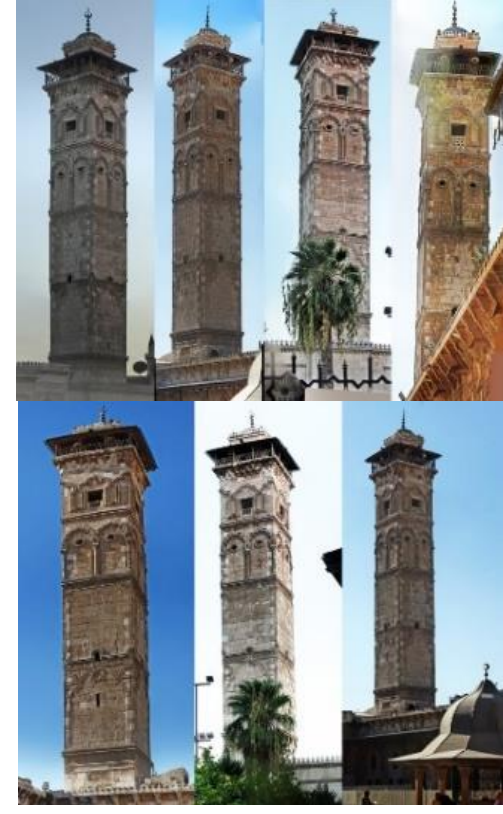

Figure 14. Some of the 22 spherical panoramas shot in 2010, used for the $3 \mathrm{D}$ reconstruction of the monuments.

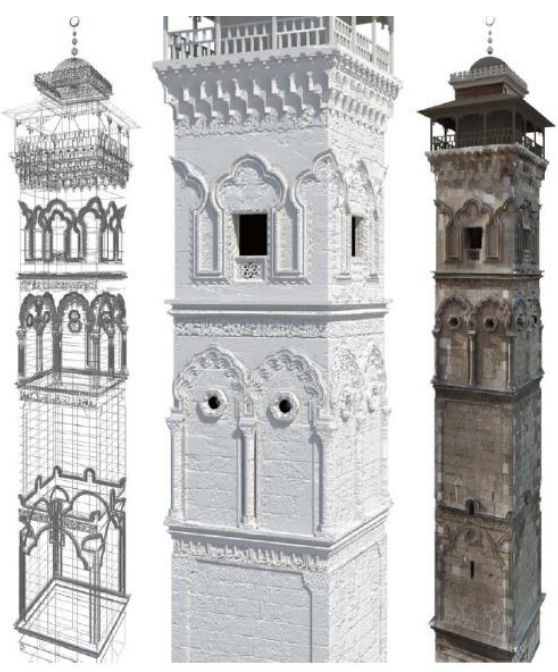

Figure 15 . The 3D model of the minaret by Wissam Wabeh.

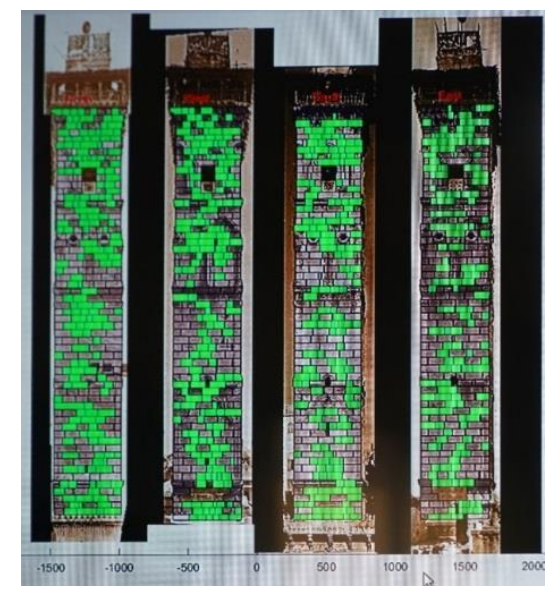

Figure 16. The blocks already identified (October 2018) in green $(40 \%$ of the 1300$)$ 


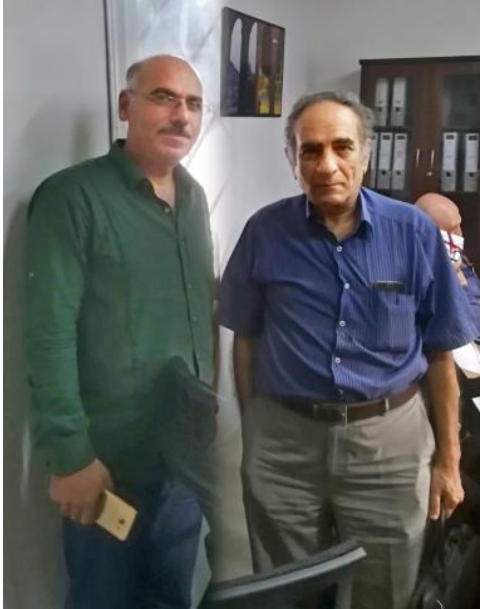

Figure 17. The A. with prof. Hassan Jabreeni, photogrammetrist (left) and prof. Ammar Kaadan, structura Eng. (right).

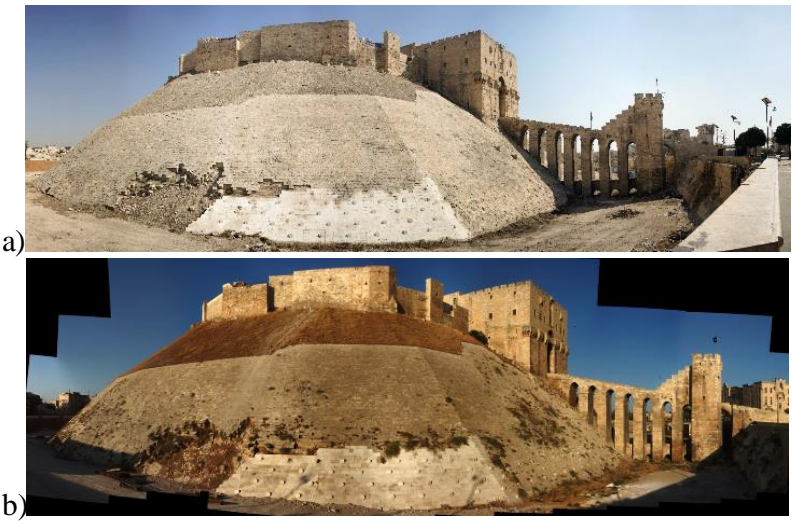

Figure 18. The Citadel walls 2018 (a), 2010 (b).

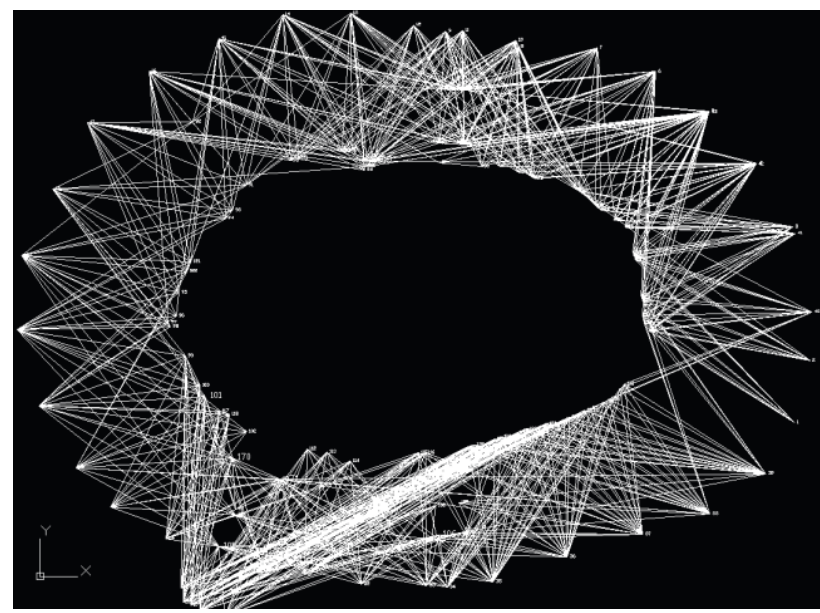

Figure 19. The 2018 control network of the Citadel, 45 panos

Figures 21 and 22 of the throne hall in the Citadel, have been produced from the same shot of Panono® camera.

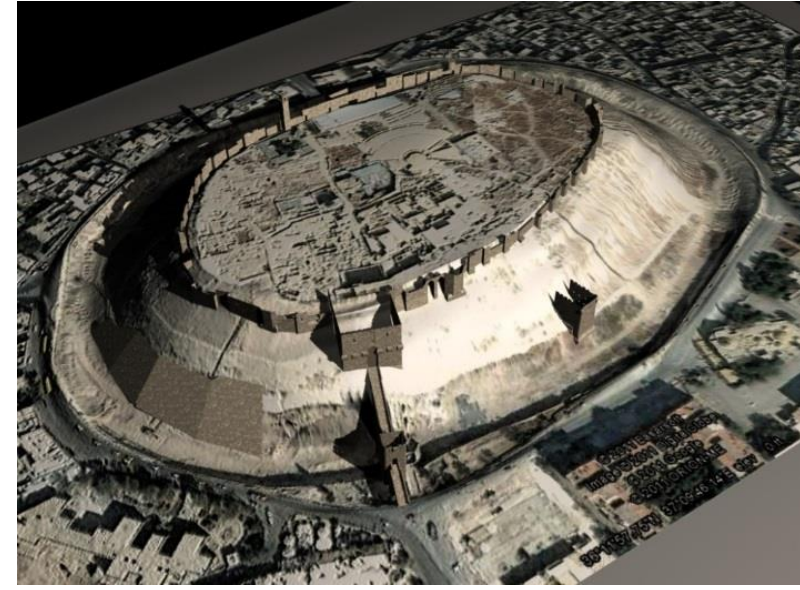

Figure 20. The 3D model of the Citadel (Livia Piemattei)

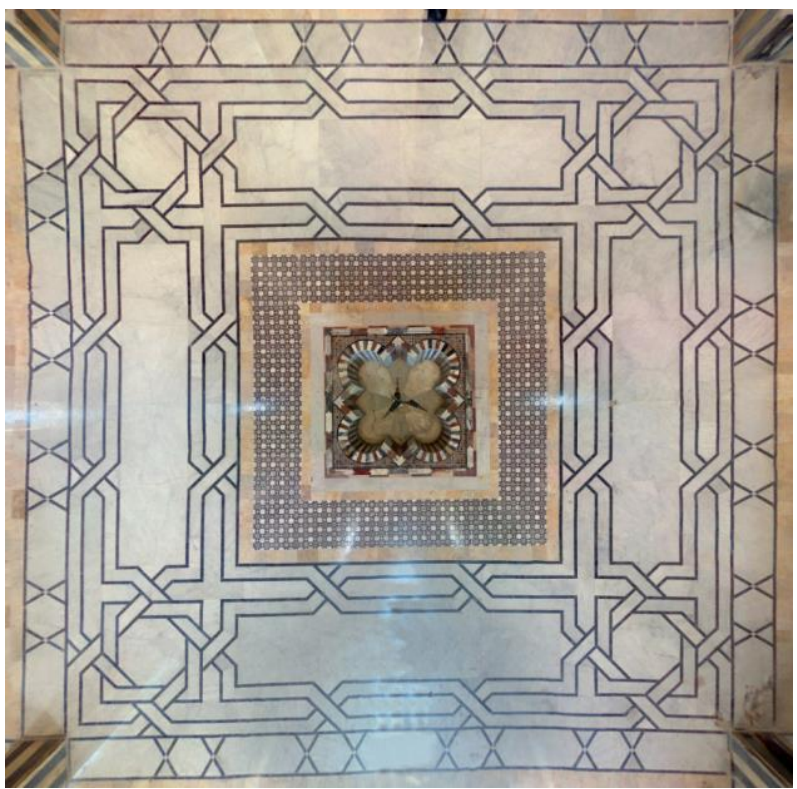

Figure 21. Citadel, the throne hall, the floor

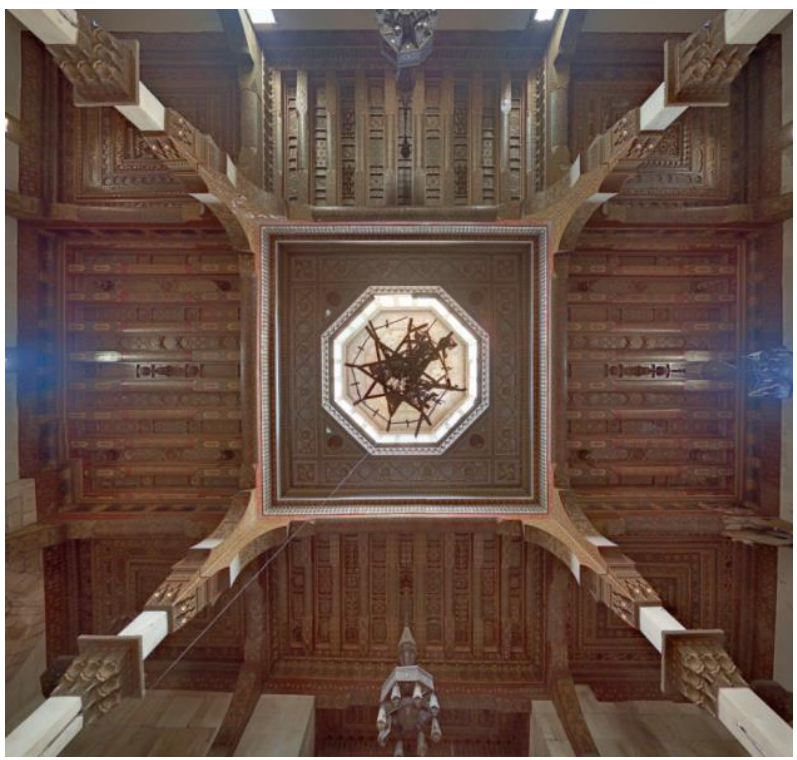

Figure 22. Citadel, the throne hall, the ceiling 


\section{CONCLUSIONS}

The plotting of the surveyed monuments will happen later hopefully in a second time. These evaluations undoubtedly prove that photogrammetric coverage is an essential instrument for the protection of the monuments. Students of the Faculty of Architecture of the University of Aleppo will probably plot the monuments. This will be the occasion to assess the damages suffered. Now some observations can already be drawn. Aleppo is included in the UNESCO World Heritage List. The majority of the monuments in the city suffered extensive damage, although they were not permanently destroyed. Apart the thousands of casualties of war, the destruction has also been concentrated on the historical center of the country, particularly against the historical buildings. The difference in color between the photographs from before and after the war is very much indicative that the buildings are now whiter and the colors are duller, which probably due to the limestone dust of the destroyed stones. The process of recovery, restoration and reconstruction will be long and difficult, and will require much effort and investment. The documentation of cultural heritage can play a small but significant part in this process

\section{ACKNOWLEDGEMENTS}

Deep gratitude goes to Dr. Reme Sakr, of the Living Heritage programme, of the Syrian Trust for Developments, to her colleague Jean, to the precious guides Rasha and Jihad for taking me around Syria and allowing me to visit and survey so many important and beautiful places.

\section{REFERENCES}

Burns, R., 1992 The Monuments of Syria I.B.TAURIS isbn 978-1-84511-947-8

Burns, R., 2017. Weaponizing monuments. International Review of the Red Cross, Vol. 99 (3), 937-957.

Di Stefano, F., 2016. Il patrimonio perduto della Siria, documentazione e archiviazione - Graduation Thesis, Università Politecnica delle Marche, Ancona

Fangi, G, Wahbeh, W., 2013. The Destroyed Minaret of the Umayy ad Mosque of Aleppo - The Survey of the Original State. European Scientific Journal, Vol. 4, pp. 7857-7881

Fangi, G., 2007. The Multi-image Spherical Panoramas as a Tool for Architectural Survey. ISPRS International Archives of Photogramm. Remote Sens. Spatial Inf. Sci, Vol. XXXVI, Part. 5/C53, CIPA Archives, Vol. XXI, pp. 311-316.

Fangi, G., 2015. Documentation of some Cultural Heritage Emergencies in Syria In August 2010 by Spherical Photogrammetry. ISPRS Ann. Photogramm. Remote Sens. Spatial Inf. Sci., Vol. II-5/W3, pp. 401-408.

Fangi, G., Nardinocchi, C., 2013. Photogrammetric Processing of Spherical Panoramas. The Photogrammetric Record, Vol. 28(143), pp. 293-311

Fangi, G., Wabeh, W., Malinverni, E., Pierdicca, R., 2016. Realized and Stored 3D Models in a Dedicated Database to
Document Some Cultural Heritage Emergencies in Syria. Proc. $10^{\text {th }}$ International Congress on The Archaeology of The Ancient Near East, Vienna, Austria, 25-29 April, 2016

Gonella, J., Khayyata, W., Kohlmeyer, K., 2005. Die Zitadelle von Aleppo und der Tempel des Wettergottes, Rhema-Verlag, Münster, ISBN 978-3-930454-44-0.

Hdjar, A., 2007. Die Denkmaeler von Aleppo. Automobile and Touring Club of Syria, Aleppo.

Silver, M., Fangi, G., Denker, A., 2018. Reviving Palmyra in multiple dimensions - Images, Ruins and Cultural Memory, Whittles Publishing, ISBN 978-1-84995-296-5.

Wahbeh, W., Nebiker, S., Fangi, G., 2016. Combining Public Domain and Professional Panoramic Imagery for The Accurate and Dense 3d Reconstruction of the Destroyed Bel Temple in Palmyra. ISPRS Ann. Photogramm. Remote Sens. Spatial Inf. Sci., Vol. III-5, pp. 81-88.

The Great Mosque of Aleppo | Muslim Heritage: http://www.muslimheritage.com

https://www.calameo.com/books/0033299721336e74edda2

http://www.sirialibano.com/siria-2/siria-distrutto

https://y outu.be/axdhppiekG4 